\title{
Om ou koeie uit die sloot te grawe: is daar lesse te leer uit die verlede? - Enkele kantaantekeninge ${ }^{1}$
}

\begin{abstract}
This article focuses on views expressed in newspaper articles and in letters to the editor about the future of Afrikaans in a new political dispensation. It seems as if people do not believe that despite the constitutional assurances of November 1993 - Afrikaans will be able to mainlain its present status as one of the official languages of South Africa as the mistakes of the past are constantly being thrown into its face. There have been signs in the business community for example by Toyola, Coca-Cola. $B M W, S A$ Breweries) and in the political arena that English, rather than Afrikaans, is the favoured language. The views expressed in the articles and letters indicate that the Afrikaans community will not accept this atritude and that a new' struggle for langwage rights (especially those of Afrikaans in the light of the history of Afrikaans) could be the result. This struggle could according to one letter writer - have serious consequences for peace in the country after the assumption of power by a new government will come to pow'er after April 271994.
\end{abstract}

\section{Inleiding}

In hierdie artikel word probeer om aan die hand van koerantberigte (hoofsaaklik vir die tydperk Julie 1993 - Januarie 1994) asook 'n aantal primêre bronne uit die taalgeskiedenis te wys op lesse wat daar uit die verlede oor die taal te leer is. Afrikaans het met sy erkenning (op 11 November 1993 in die Parlement in Kaapstad) as een van die elf amptelike tale van die Nuwe Suid-Afrika daarin geslaag om sy status as amptelike taal te behou (ten spyte van die verwagtinge in baie kringe dat dié taal hierdie status ontneem sou word). Die realiteit toon egter

1 Hicrdic artikel is dic aangepaste en verwerkte teks van 'n referaat wat gelewer is tydens 'n kongres oor Afrikaans in een veranderende context: Taalkundige en letterkundige aspecten by dic Vrije Universiteit van Ansterdam. Nederland van 19-21 Januaric 1994 
dat die grondwetlike erkenning van Afrikaans nie noodwendig beteken het dat die taal nou 'n nuwe groeifase binnegaan nie; inteendeel: Afrikaans kry swaar om sy status te bly handhaaf op verskeie gebiede. In dié artikel sal gewys word op aspekte wat soos in die verlede ' $n$ invloed het/gehad het op die groei en bevordering van Afrikaans. Die interessantheid lê juis daarin: telkens as probeer is om Afrikaans te onderdruk, het dit soos 'n bal wat onder die water gedruk word, weer na bo geskiet. Die ou koeie wat voortdurend uitgegrawe word (soos nasionalisme en apartheid) en in Afrikaans se gesig gegooi word, is by tye dus eintlik teenproduktief vir diegene wat Afrikaans sy status en voorregte probeer ontneem hoofsaaklik omdat dit 'n nuwe bewuswording van Afrikaans en 'n emosionele dryfveer vir die bevordering van die taal tot gevolg het.

\section{Afrikaans in die brandpunt}

'n Mens hoef slegs die nuusberigte en briewekolomme van koerante die afgelope paar maande dop te gehou het om te sien hoedanig die kwessie van taal - en die saak van Afrikaans in die besonder - is. Opskrifte soos die volgende (geselekteerde) berigte gee alreeds ' $n$ sterk aanduiding dat ons hier met 'n hoogs kontensieuse en emosionele kwessie te doen het: "Afrikaans bedreig - Dié wat aan die taal torring, sal g'n rus hê" (Beeld, 15/5/1993), "Streke - maar wat van Afrikaans?" (Rapport, 11/7/1993), "Staan op vir Afrikaans! - Breyten" (Rapport, 18/ 7/1993), "Afrikaans: SAUK moet weer dink" (Beeld, 29/10/1993), "Afrikaans dan enigste taal wat regte prysgee" (Beeld, 21/8/1993), "Afrikaans is 'n "taal van die mense', sê Mandela" (Beeld, 15/9/1993), "Afrikaans suig aan agterste speen in handel" (Beeld, 30/10/1993), "Gee ons taalvrede" (Rapport, 31/10/1993), "Afrikaans verloor veld op kampus" (Rapport, 31/10/1993), "Behoeders van taal uitoorlê" (Beeld, 2/11/1993), "SAUK en Afrikaans - Gilde tree toe tot stryd" (Beeld, 3/11/1993), "Afrikaans: Miljoene se menswees dan misken" (Beeld, 3/11/1993), "Afrikaans word 'stelselmatig by deure, vensters uitgesmyt" (Beeld, 3/11/1993), "Afrikaners het nou al genoeg agteroor gebuig" (Beeld, 4/11/1993), "Derde taalbeweging - Afrikaans se grootste behoefte: om bevry te word" (Beeld, 6/11/1993), "Los ons taal uit, dreig Afrikaners - Taalstryd kan oor grense saambind" (Rapport, 7/11/1993), "Die taalbesluit van Kemptonpark - Die les wat die Afrikaner nooit weer moet vergeet nie" (Beeld, 12/11/1993), "Groot kompromis - Baie vrae oor Suid-Afrika met sy elf ampstale" (Beeld, 12/11/ 1993), "Nou begin die kwelvrae oor Afrikaans" (Rapport, 14/11/1993), "Afrikaans stiefkind op SAL se vliegtuie" (Rapport, 14/11/1993), "En nou, Afrikaans?" (Rapport, 14/11/1993), "Viva! Afrikaans" (Beeld, 16/11/1993), "Nie regverdige taalgelykheid" (Beeld, 17/11/1993), "Wat is presies oor taal besluit?" (Beeld, 18/11/1993), "Vrac aan SAUK oor taalbeleid" (Beeld, 18/11/1993), "Die taal-stertjie - Beleid oor elf tale is nog vol vrae" (Beeld, 19/11,1993), "Regering bepaal die lot van ' $n$ taal - op Engels" (Rapport, 21/11/1993), "Taal ook in TOD onderdruk" (Rapport, 21/11/1993), "'n Miljoen gesoek - Nou is die tyd om slag 
onderdruk" (Rapport, 21/11/1993), "'n Miljoen gesoek - Nou is die tyd om slag te slaan vir Afrikaans" (Beeld, 22/11/1993), "Afrikaans nie oorgelaat aan willekeur van streke" (Beeld, 25/11/1993), "Hou op soebat, Afrikaner" (Rapport, 28/11/1993), "Afrikaners sal baadjies moet uittrek vir taal" (Beeld, 30/11/1993), "Basta met ekskuus vra oor Afrikaans" (Rapport, 5/12/1993), "Afrikaans: Tradisie moet voortgesit word" (Beeld, 7/12/1993), "Afrikaanssprekendes moet tot massa-aksie oorgaan vir taal" (Die Burger, 11/12/1993), "Afrikaans - die broeiende storm" (Rapport, 12/12/1993), "Afrikaanse klante nie so welkom by party instansies" (Die Burger, 13/12/1993), "Besluit oor elf amptelike tale vir SA is sommer net skelm" (Die Burger, 13/12/1993), "Veg vir Afrikaans" (Die Burger, 13/12/1993), "Behoud van Afrikaans meer as ooit in die hande van sy sprekers" (Die Burger, 14/12/1993), "Ons sal moet optree om Afrikaans te red" (Rapport, 19/12/1993), "Geen Afrikaans, geen geld" (Rapport, 19/12/1993), "Moet ons werklik weer begin met 'n taalstryd?" (Die Burger, 20/12/1993), "Afrikaanstaliges is geregtig om hul eie taal te gebruik" (Die Burger, 20/12/ 1993), "Afrikaans se status word geensins ingekort nie" (Die Burger, 24/12/ 1993), "Só maak hulle die Afrikaner moeg en slap oor sy taal" (Die Burger, 29/12/1993), "Ná 300 jaar in SA word ons taal se nek omgedraai" (Die Burger, 29/12/1993), "Oomblik van ware bevryding naby vir Afrikaner en sy taal" (Die Burger, 30/12/1993), "Taalartikel in Grondwet moet hersien word" (Die Burger, 30/12/1993), "Staan nou saam vir Afrikaans" (Rapport, 2/1/1994), "Afrikaans "sal nie by oordrewe taalstryd baat vind nie"" (Die Burger, 4/1/1994), "BierblikAfrikaans: Gesanik hang my by die keel uit!" (Beeld, 6/1/1994), "Strategie vir taalstryd" (Rapport, 9/1/1994), "Dis mense wat lotgeval van Afrikaans bepaal" (Beeld, 19/01/1994), "Voortrekkers kan só 'veg' vir Afrikaans" (Beeld, 27/01/ 1994), "Afrikaans kry in RGN-vereniging die trekpas" (Beeld, 27/01/ 1994), "Kriegler en kommissie moet oor taal weer besin" (Beeld, 28/01/1994), ensovoorts.

Dié reaksie wat hier bo verwoord is, is ' $n$ refleksie van die verontwaardiging en ongelukkigheid wat in Afrikaanse geledere heers oor die wyse waarop Afrikaans gehanteer word in die oorgangsproses na 'n nuwe grondwetlike bedeling. Aan die een kant is daar die versekering (dikwels van owerheidswee af) dat Afrikaans se posisie deeglik verskans is in die talebeleid wat by Kemptonpark beding is, maar die realiteit wys dat hierdie versekering nie veel werd is nie. Die toekoms van Afrikaans is byvoorbeeld beding in Engels (soos een van die briefskrywers hier bo dan ook opgemerk het), Afrikaans word al hoe meer deur die SAUK afgeskeep in sy programme en van gelykberegtiging is daar tans al hoe minder sprake (d.i. veral ná die aanstelling van die nuwe SAUK-raad in 1993), in die handel word al hoe meer voorkeur gegee aan Engels as handelstaal (vgl. byvoorbeeld die herrie in die pers oor die verklaring van die Toyota-motormaatskappy 
dat hulle nie meer Afrikaanse handleidings gaan uitgee nie ${ }^{2}$, asook op dié van Coca-Cola en SAB dat hulle nie meer Afrikaans op hulle blikkies gaan gebruik nie $^{3}$ ) - dit alles hoewel in die Oorgangsgrondwet uitdruklik verklaar word: "Regte met betrekking tot taal en die status van tale wat by die inwerkingtreding van hierdie Grondwet bestaan, word nie ingekort nie..." (Hoofstuk 1, 3(2) van die Oorgangsgrondwet). Dié siening word beaam deur 'n hoofartikelberig in Die Burger (13/11/1993):

Die feite is daar vir almal om te sien. Afrikaans behou volgens ' $n$ besluit van die Onderhandelingsraad sy posisie as een van die amptelike tale, maar in die praktyk beskou sommiges die koms van die nuwe grondwetlike bedeling blykbaar as 'n geleentheid om Afrikaans by die agterdeur uit te gooi ... Ná dekades van oorgerustheid oor die posisie van Afrikaans behoort die oproep van Gustav Preller in 1905 herhaal te word in die nuwe omstandighede waarin die taal hom bevind: 'Laat 't ons toch ernst wezen'. (My kursiverings - WAMC.)

'n Mens kan ten opsigte van hierdie aspek seker wel argumenteer dat die klousules in die Grondwet nie betrekking het op private ondernemings nie, en dat daar nie van sake-instansies verwag kan word om gehoor te gee aan hierdie klousules as dit hulle geld uit die sak jaag nie, maar die morele verpligting van die erkenning van individue se taalregte kan uit ' $n$ sake-oogpunt ook nie weggeredeneer word nie.

Dis asof daar by baie Afrikaanssprekendes die siening begin posvat dat hulle self iets moet doen om hulle taalregte op te eis - dit word byvoorbeeld weerspieël in verskeie van die briewe en berigte die afgelope tyd waarin die slagspreuke van die verlede weer aangehaal word: "Is 't ons ernst?" (J.H. Hofmeyr, Maart

2 Vergelyk in hierdie verband koerantopskrifte soos die volgende: "Dié Toyotas gaan net in Engels werk" (Beeld, 31/11/1993), "Hou dit Afrikaans" (Beeld, 1/12/1993), “Ander vervaardigers se motors gaan steeds op Afrikaans werk" (Beeld, 1/12/1993), "Toyota maak omkecr or Afrikaans ná wye kritiek" (Beeld, 2/12/1993), "Alles loop reg met Toyota-Afrikaans en Tolla wil sing" (Beeld, 3/12/1993), "n Kort skande altyd beter as 'n lang verdriet" (Beeld, 4/12/1993), "ATKV pak BMW oor Afrikaans" (Beeld, 7/12/1993), "Blydskap oor Toyota se bekering" (Beeld, 8/12/1993), "'n Voorbeeld vir advertecrders" (Beeld, 8/12/1993), cns.

3 Kocrantopskrifte oor hierdic aangeleentheid gec duidelik blyke van verontwaardiging "Coke, SAB-bier skuim nie Afrikaans" (Beeld, 9/12/1993), "Storm oor Afrikaans . . ná Coke en Brouerye besluit op net Engels vir blikkies" (Die Burger, 9/12/1993), "Afrikaanslose blikkies" (Die Burger, 9/12/1993), "Storm woed voort oor taal op produkte - elf tale net rookskerm. sê minister" (Die Burger, 10/12/1993), "Só kry Afrikaans léwe" (Die Burger, 10/12/1993), "SAB, Coke-verspreider skop vas oor Engels" (Die Burger, 11/12/1993), "Afnkaans sal bly op Coke-bottels" (Sake-Kapport, 12/12/1993), "Dis dalk nou tyd dat Afrikaners begin toi-toi" (Die Burger, 16/12/1993), ensovoorts 
1905), "Laat 't ons toch ernst wezen!" (G.S. Preller, April-Junie 1905), "Het is ons ernst" (D.F. Malan, Augustus 1908). Die sterkste oproep in hierdie verband is egter dié van die (huidige) voorsitter van die Taalkommissie, prof. Johan Combrink: "Afrikaanssprekendes moet tot massa-aksie oorgaan vir taal" (Die Burger, $11 / 12 / 1993$ - p. 13). In sy artikel voer hy onder meer aan dat ons hier met 'n Derde Afrikaanse Taalstryd te make het “... waaraan álle Afrikaanssprekendes kán deelneem en behóórt deel te neem", want "(o)ns taal word geminag en verguis deur leiers en beplanners en organiseerders in die sakewêreld, die nywerhede, die sportwêreld, die politiek en die wêreld van die wetenskap". Die vraag is dan: "Wat doen ek as Afrikaanssprekende daaraan? Wat doen u as Afrikaanssprekendes daaraan?" Die tyd is verby dat die "regering" sorg vir die taal se voortbestaan deur wette, regulasies en subsidies. "Ons tien beste stryders vir Afrikaans vind ons aan die einde van ons twee arms. Ons moet elkeen, self, én almal saam, nou dinge doen vir Afrikaans". As ons dit nie doen nie, "... gaan Afrikaans weer 'n kombuistaaltjie wees oor twintig jaar". Daarom moet ons “... elkeen, elke keer, van ons laat hoor, ons moet ons elke keer laat voel, as Afrikaans te na gekom word." Briewe moet direk geskryf word aan firmas en instansies wat Afrikaans swak behandel. (Die assistentredakteur van Rapport, dr. Piet Muller, eggo laasgenoemde sentiment baie sterk in sy rubriek van 19/1/ 1994 as hy ' $n$ "strategie vir ('n) taalstryd" aangee en onder meer die telefoonnommers van die hoofde van $\mathrm{SAB}$ en Coca-Cola verskaf sodat persone direk kan skakel met hulle klagtes, want "' $n$ (l)es wat ' $n$ taalstryder gerus betyds moet leer, is dat dit nie help om te gesels met skakelbeamptes en spesiale foonnommers wat deur maatskappye beskikbaar gestel word nie" - Muller, 1994:14.) Prof. Combrink voer verder aan dat ons geen verskoning hoef aan te teken as ons Afrikaans gebruik nie.

Ons staan regop vir ons taal, sonder skuldgevoel, sonder apologie en ons sê: My taal is my geld werd. Afrikaans is 'geldig'.

Hy wonder of dit nie tyd is vir verbruikersboikotte soos dié wat die laaste paar jaar deur swart drukgroepe gevoer is nie.

Ons het ' $n$ magtige wapen: ons beursie ... Sonder Afrikaanse behandeling, geen Afrikaanse geld ... Ons, die gewone mense, het ekonomiese mag. Laat ons dit reg gebruik.

Die betoog word afgesluit met die volgende stelling:

Of ons is self elke dag ernstig oor Afrikaans, of Afrikaans sal in die volgende paar jaar emstig agteruitgaan. Ons moenie kla oor wat ander aan Afrikaans doen nie. Ons moet elkeen self doen wat ons kan doen vir Afrikaans. Ons taal is ons geld werd (Die Burger, 11/12/1993). 
Dr. Piet Muller (Rapport, 28/11/1993) sluit hierby aan as hy sê dat die adverteerder wat sy neus vir Afrikaans optrek, nie kan bekostig om die potensiaal van die Afrikaanse mark (ongeveer R60 miljard per jaar) te ignoreer nie.

As elke Afrikaanssprekende net wil onthou dat hy of sy in die eerste plek ' $n$ verbruiker is, wie se geld hard praat, kan elke taalskermutseling gewen word.

Die skrywer Abraham de Vries (Die Burger, 14/12/1993) meen dat die kwessie van 'n produkteboikot selfs verder gevoer kan word as bloot net die weiering om sekere produkte van vervaardigers wat Afrikaans afskeep te koop. Politici wat deel gehad bet aan die bedinging van Afrikaans se posisie in die Oorgangsgrondwet - "die vroom besluite oor die behoud van die taalregte en statute ten spyt" moet bewus wees van 'n verdere boikot: "praat my taal of jy verloor my stem".

\section{Emosies en taalpolitiek}

Al hierdie berigte en oproepe kom neer op een belangrike kwessie: taal bly ' $n$ hoogs emosionele saak en daar kan nie ligtelik daarmee gehandel word nie - (vgl. Swanepoel, 1992). Die verlede het al genoeg bewyse hiervoor verskaf - daarvoor kan ' $n$ mens net sorgvuldig die geskiedenis van Afrikaans sedert die begin van die 19de eeu nagaan en dan kennis neem van die emosies wat losgemaak is toe die taal van die tyd nie na waarde geskat is nie. Dr. Piet Muller (1993a:18) waarsku dat die bewindhebbers van hierdie tyd (en dan beslis die nuwe bewindhebbers ná die verkiesing op 27 April 1994) versigtig te werk moet gaan met die hele talekwessie en dat hulle nie moet vergeet nie " $\ldots$ dat wie nie die lesse van die geskiedenis wil leer nie, gedoem is om die foute van die verlede te maak" (Rapport, 31/10/1993). Volgens hom kom dit voor asof Suid-Afrika weer te doen gaan hê met 'n nuwe taalstryd - "net omdat daar mense is wat weier om uit die verlede te leer en doelbewus besig is om Afrikaanssprekendes in 'n hoek te druk". So iets kan net teenproduktief wees, want die opstand van die verlede sal net herhaal word. Iets hiervan word al waargeneem in die optrede van Afrikaanssprekendes wat deesdae meer geneig is om aan te dring op Afrikaans as enkele jare gelede - soos hy sê: "Net om 'n punt te maak." Hierdie ingesteldheid lei weer tot 'n groter bewuswording van die ou verbintenis tussen taal en nasionaliteit (wat Afrikaans oor die jare ongelukkig ook seergemaak het - vgl. Zietsman, 1992) "... omdat mense instinktief aanvoel dat as daar vir hulle taal in die nuwe Suid-Afrika nie ' $n$ plek is nie, daar vir hulle ook nie 'n plek sal wees nie". Hulle taal word afgeskeep in die handel, die politiek, die sportwêreld, die nywerheid, die wetenskap, die radio en televisie en hulle sal dit op die lang termyn nie gelate bly aanvaar nie. Reeds word daar gedreig met verbruikersboikotte teen maatskappye se produkte indien die maatskappye nie Afrikaans gelykberegtig nie. Toyota het byvoorbeeld vinnig hulle posisie verander toe gedreig is met 'n boikot 
en die finansiële implikasies daarvan ingesien is. 'n Rekenaarmaatskappy wat besluit het om nie meer in Afrikaanse publikasies te publiseer nie en ook om nie kennis van hulle aktiwiteite aan Afrikaanse joernaliste deur te gee nie, moes agtien maande later van siening verander omdat daar geen berigte meer oor hulle in Afrikaanse koerante verskyn het nie en omdat groot Afrikaanse maatskappye al hoe minder van hulle produkte gekoop het (vgl. Rapport, 28/11/1993). F.I.J. van Rensburg (Beeld, 28/01/1994) sê dat hierdie soort besluite om sensitiwiteitsoorwegings alleen alreeds nie aanvaar kan word nie:

Daardie selfde grondwet waarop individue en instansies hulle beroep wanneer hulle tot ' $n$ enkeltalige oplossing besluit, bepaal uitdruklik dat die regte en gebruike van die huidige amptelike tale nie verminder mag word nie (Van Rensburg, 1994:8).

Die ou koei van apartheid word byvoorbeeld ook voortdurend uit die sloot bygetrek as Afrikaans ter sprake kom - jy is ' $n$ Afrikaanssprekende en sommer by implikasie ook ' $n$ rassis, want Afrikaans is mos die taal van apartheid. Deesdae loop ' $n$ mens selfs in sommige kringe die gevaar om as rassis of ver-regse aangesien te word as jy hoegenaamd vir jou taal in die bresse tree! (Vgl. Rapport, 31/10/1993 - "Gee ons taalvrede"; ook Hans du Plessis 1992:37.) Dat hierdie argument nog steeds opgehaal word, kan 'n mens sekerlik verstaan, want dis waar dat 'n onaanvaarbare politieke beleid deur middel van Afrikaans uitgevoer is:

Afrikaans het by uitstek die taal geword waarin apartheid uitgedink, geregverdig, gepropageer en uitgevoer is. Dit het ... daartoe gelei dat Afrikaans mettertyd met onreg, lyding en verdrukking vereenselwig is en vir baie die gehate apartheidstaal geword het (Zietsman, 1992:200; vgl. ook Zietsman, 1992:2).

Dis egter nog nie te sê dat die taal Afrikaans self apartheid uitgevoer het nie eerder het die sprekers van Afrikaans dit gedoen, soos Van Rensburg (1989) reeds uitgewys het. Prof. Jakes Gerwel (soos aangehaal in L.T. du Plessis 1992: 98-97) vat hierdie sentiment só saam:

Ons kan nie die arme, blerrie taal gaan blameer vir wat ons as mense doen nie. Dis sy sprekers wat dit doen. Dis die omgewing waarin hy hom vind.

Die teendeel is daarom ook waar: vir baie mense het Afrikaans weer juis die taal van bevryding geword, die taal waarmee die juk van apartheid afgeskud is (vgl. L.T. du Plessis, 1992:100 e.v., Zietsman, 1992:202 e.v.) 'n Uitspraak soos die volgende deur Van de Rheede (1983:32-33) illustreer hierdie uitgangspunt:

Die Afrikaans van die statutêr geklassifiseerde Kleurling het die Afrikaans geword waarin hewig protes aangeteken word teen apartheidstrukture: dit het die Afrikaans geword waarin uiting gegee word aan lyding as gevolg van rassediskriminasie; dit het die Afrikaans geword waarin politieke kri- 
sisse georganiseer is. Ja, die Afrikaans van die 'Kleurling' het 'n nuwe semantiese inhoud gekry. Dit het bevrydingsafrikaans geword ...

Volgens 'n berig in Die Burger (27/01/1994: 14) het die (huidige) Admmistrateur van Kaapland, mnr. Kobus Meiring, bogenoemde siening beaam in 'n toespraak voor die Voortrekkers:

Afrikaans is ' $n$ taal van bevryding. Dit is ' $n$ taal van verskeie groepe, van versoening, heropbou en vir die toekoms. Dit is beslis nie ' $n$ kombuistaal nie en dit is nie die eksklusiewe eiendom van sekere politieke bewegings nie. Afrikaans is ook nie ' $n$ taal van verdrukking en haat nie.

Die 'foute' van die verlede behoort gevolglik ook vanuit ' $n$ ander perspektief beoordeel te word en nie net voortdurend as kapstok vir 'n hernieude geseling te dien nie (vgl. Webb, red. 1992 vir beskouings oor Afrikaans ná apartheid.) F.I.J. van Rensburg (1993:9) waarsku dat ons hier met 'n les te doen het "... wat die Afrikaner nooit weer moet vergeet nie: wat een groep Afrikaanssprekendes doen, het gevolge vir alle ander Afrikaanssprekendes". Dis daarom goed om te besef “... dat Afrikaans veel meer as selfs ' $n$ witmenstaal is. Sy wortels lê diep in die geskiedenis van die bruin en Maleiergemeenskap, en sy takke strek via Fanakalo en Tsotsi- of Fly-taal tot ver in die swart gemeenskappe" (Hoofartikelberig, Beeld, 20/8/1993:8).

Dat Afrikaans nie alleenbesit van die wit Afrikaner is nie, is net so ' $n$ uitgediende en afgesaagde opvatting as dat Afrikaans net apartheidstaal of taal van die onderdrukker is. Dit is tyd dat ons in die gesprek oor tale wegkom van stereotiepe oor taal ... van stereotiepe oor Afrikaans ...

Aldus Hans du Plessis (1992:24)(my kursivering - WAMC).

En ook:

Al sou Afrikaans dus die simboolwaarde van onderdrukkerstaal hê, is dit as sodanig nie genoeg rede om dit sy amptelikheid in 'n nuwe Suid-Afrika te ontneem nie (Du Plessis, 1992:49).

Dis daarom dat die redakteur van Rapport, 1.L. de Villiers, waarsku dat "'n afgeknoude taal ... 'n onbeskaamde politieke stormram (word)" (Rapport, 24/10/ 1993). Dit word onder meer verder gestook deur die persepsie wat

.. besig is om by Afrikaanssprekendes te ontstaan dat hulle taal in die geboorte van 'n nuwe bedeling in die gedrang kom: dat ' $n$ nuwe politieke elite Afrikaans anders - en nie beter nie - as in die afgelope dekades gaan behandel. En dit is politieke dinamiet - in enige taal ... Want die geskiedenis leer dat 'n taalgemeenskap wat misken word ook 'n politieke storm kan ontketen. En 'n taalgemeenskap wat sy geledere teen verontregting sluit, neem toe in strydlustigheid (Rapport, 12/12/1993:20). 
Die gevaar bestaan volgens De Villiers (1993b:20) daarin dat taalstryde “... dikwels die aanjaers van verskeie soorte nasionalismes (is): van die gematigde, wellewende maar tog trotse soort tot die militante en selfgeldende tipe" (Rapport, 12/12/1993). Volgens dr. Piet Muller (1993a:18) kan dit 'n regering daarom net loon as hulle kennis neem van ' $n$ belangrike beginsel: " $n$ Land wat vrede begeer, behoort nie met die tale van sy burgers skoor te soek nie" (Rapport, 31/10/1993). I.L. de Villiers (1993b:20) voeg hierby:

Politieke partye sal hierdie doringbos versigtig moet hanteer ... Hulle kan nie slegs een taalvlag hys nie. Maar hulle kan ook nie goedsmoeds of stilweg 'n taalvlag stryk en wegbêre nie (Rapport, 12/12/1993).

F.I.J. van Rensburg (1993:9) sluit hierby aan as hy met verwysing na die taalbesluit van Kemptonpark sê dat 'n groot gevaar vir vrede in die land afgeweer is met die kompromisbesluit oor Afrikaans en die ander tale van Suid-Afrika:

Wie sy taalgeskiedenis ken en bewus is van wat kan gebeur as ' $n$ taal sy ampstaalstatus verloor, weet vandag dat ' $n$ ernstige gevaar afgeweer is - nie net vir Afrikaans nie, maar ook vir vrede in die land (Beeld, 12/11/1993).

'n Briefskrywer in Die Burger (20/12/1993:8) sê dat die taalverlede van hierdie land ' $n$ paar belangrike voorbeelde oplewer

... wat toon dat dit onwys is om politieke besluite oor taal te neem, veral as dit geskied in die aangesig van groot teenstand en nie met die feitelike sterk posisie van Afrikaans in Suid-Afrika rekening hou nie. So iets sal niks goeds voorspel nie.

Die ou verband tussen Afrikaans en landspolitiek - maar ook taalpolitiek - kom dus telkens weer ter sprake. Vervolgens word kortliks op enkele aspekte daarvan gewys.

\section{Uit die verlede: Afrikaans se wil om te oorleef}

Tot en met die 1976-onluste in Soweto is redelik algemeen aanvaar dat Afrikaans nie probleme gaan hê om sy posisie in hierdie land te handhaaf nie. Die gebeure rondom die onluste en veral die aanleiding daartoe, was egter 'n groot skok vir Afrikaansgesindes, want ewe skielik was Afrikaans weer in die brandpunt van politieke woelinge. Sedertdien het verskeie belangwekkende bronne verskyn waarin opnuut besin is oor die posisie van Afrikaans in hierdie land en was daar ook 'n belangrike herwaardering van die geskiedkundige feite rondom Afrikaans. J.C. Steyn se Tuiste in eie taal: die behoud en bestaan van Afrikaans (1980) het in hierdie opsig die toon aangegee deur 'n wetenskaplike kyk op verskeie faktore wat 'n rol kan speel op die groei of kwyn van 'n taal. Dié boek is in 1984 opgevolg met 'n bundel Afrikaans: stand, taak, toekoms (K.P. Prinsloo \& M.C.J. 
van Rensburg reds.) waarin verder uitgebrei is op die sienings van Steyn en onder meer oor die posisie van Afrikaans in Afrika besin is. L.T. du Plessis se Afrikaans in beweging (1986) het wel kontroversie rondom die taalbeweging-debat meegebring, maar tog ook interessante nuwe perspektiewe verskaf op die taalpolitiek rondom vroeë Afrikaans. J.C. Steyn se Trouwe Afrikaners: aspekte van Afrikaner-nasionalisme en Suid-Afrikaanse taalpolitiek 1875-1938 (1987) het uitgebreid gewys op die rol wat Afrikanemasionalisme gespeel het in die groter bewuswording van die verband tussen taal en volk in Afrikaans se wordingsjare. H. du Plessis en L.T. du Plessis (reds.) se Afrikaans en taalpolitiek: 15 opstelle (1987) het die debat oor taalpolitiek en veral die rol daarvan in Afrikaans se verlede verder belig. Aanvullende bronne met ander perspektiewe in hierdie verband is Hans du Plessis se En nou, Afrikaans? (1992) (waarin geargumenteer word vir die behoud van Afrikaans in 'n nuwe politieke bedeling) en die ietwat voortydige Afrikaans ná apartheid (V.N. Webb red., 1992). 'n Bron waarvan nog nie na behore kennis geneem is nie, is P.H. Zietsman se voortreflik nagevorsde boek Die taal is gans die volk: Woelinge en dryfvere in die stryd om die Afrikaner se taal (1992) waarin hy wys op die woelinge en aktiwiteite rondom die posisie van Afrikaans in "... die tydperk met die uitbreek van die AngloBoereoorlog in 1899 tot met die herwinning van Afrikanermag in 1907-1908" (Zietsman, 1992:2). Alles is hiermee waarskynlik nog nie gesê oor die pogings wat in die verlede aangewend is om Afrikaans se posisie te versterk nie en dit sal ook nie moontlik wees om dit hier te doen nie. Daarom word in die res van hierdie afdeling slegs kortliks stilgestaan by enkele tersaaklike aspekte van ' $n$ interessante periode, naamlik dié tussen 1899-1910 om te illustreer dat mense nie noodwendig ongeèrg bly as hulle taal ter sprake kom nie.

Reeds tydens die Anglo-Boereoorlog is pogings deur die Britse owerheid onder leiding van lord Alfred Milner aangewend om Engels as taal van die onderwys in die konsentrasiekampe te bevorder. Die argument is by herhaling opgehaal dat Engels die toekomstaal is van die nuwe politieke bedeling (dit is die verwagte assimilasie van die Afrikaner in die Britse ryk) wat deur die Britse owerheid beoog is. $\mathrm{Na}$ afloop van die oorlog was die Afrikaners ' $\mathrm{n}$ verslane nasie in verskeie opsigte: demografies gesproke was die bevolking baie uitgedun, Hollands is uit verskeie van sy hoë funksies verdring en beperkte geleentheid is gegee om Hollands op skool te onderrig (Hollands mag byvoorbeeld 'n maksimum van vyf uur per week as vak op skool onderrig word terwyl die res in Engels was; Hollands se rol en funksies in die staatsdiens is heeltemal afgeskaal en in sommige gevalle selfs afgeskaf), groot groepe Britse immigrante het die land binnegestroom en tradisionele werksgeleenthede van Afrikaans-/Hollandssprekendes oorgeneem. Die gevolg hiervan was 'n gedemoraliseerde bevolking wat weinig hoop op die toekoms gehad het. Daar is wel probeer om gelyke taalregte (vir Hollands en Engels) te beding, maar daarmee is slegs beperkte sukses behaal toe toegegee is dat Hollands op ouers se versoek in skole toegelaat kon word (Zietsman, 1992:37-39). 
Genl. J.C. Kemp het egter gewonder wat baat so 'n reëling in die lig van Milner se verklaring dat hy slegs een taal (nl. Engels) in Suid-Afrika wou hê (vgl. Zietsman, 1992:38). Die geleidelike bewuswording dat probeer is om die Afrikanervolk te vernietig deur hom van sy taalregte te ontneem, het al hoe sterker toegeneem. Zietsman (1992:39) sê "(d)ie idee dat die volk deur sy taal weer volk kon word, was 'n vonk van verset ..." wat spoedig al hoe wyer in 'n volks- maar ook taalnasionalistiese gevoel begin uitkring het - vandaar dan ook die spreuk "de taal is gansch het volk" (vgl. Zietsman 1992:58-62). Die strydperk was dus in wese voorberei vir 'n soort taalstryd, alhoewel dit eintlik 'n stryd om die behoud van Hollands was aangesien Afrikaans op daardie stadium nie veel meer as 'n spreektaal (en 'n wordende skryftaal) was nie.

Steyn (1980:182) sê dat daar drie elemente nodig is vir die voer van 'n geslaagde taalstryd, naamlik (i) 'n bevolking wat nog sy taal kan praat, (ii) 'n nasionale of ekonomiese prikkel en laastens ook (iii) 'n groep taalbewuste en taalgetroue intellektuele leiers. Die situasie was gereed hiervoor: ná die Anglo-Boereoorlog is Afrikaans nog oorwegend as huistaal gebruik, die prikkel was die vernederende neerlaag in die oorlog en daar was genoeg taalbewuste en taalgetroue leiers (soos F.S. Malan, Louis Botha, G.S. Preller, J.H.H. de Waal, J.H. Hofmeyr, D.F. Malan, D.F. Malherbe, e.a.). Gesamentlik het hierdie drie faktore gelei tot 'n groter aandrang op die erkenning van Afrikaans - ook as skryftaal en as landstaal. Hierdie strewe is verder aangevuur deur die stigting van organisasies soos die Afrikaanse Taalgenootskap (Desember 1905) (met as doel: “(a) Afrikaners te o'ertuig dat Afrikaans onse taal is, en dat die deur Afrikaners als hul spreek- en skrijftaal behoort gebruik te worde; (b) ontwikkeling van die Afrikaanse taal in suiwere vorm; (c) aankweking en ontwikkeling van 'n suiwer Afrikaanse nasionaliteitsgevoel" - vgl. Pienaar, 1943:271) en die Afrikaanse Taalvereniging (November 1906) (met as hoofdoel "... om di gebruik van suiwer Afrikaans als spreek- sowel as skrijftaal aan te moedig, en om meer liefde en waardering bij ons volk daarvoor op te wek" - vgl. Pienaar, 1943:287).

Daar was ook die bekende "ernst"-toesprake: "Is 't ons ernst?" deur J.H. Hofmeyr op 6 Maart 1905 te Stellenbosch, G.S. Preller se reeks vervolgartikels in De Volkstem (19 April - 14 Junie 1905) onder die opskrif "Laat 't ons toch emist wezen!" (waarin hy onder meer aanvoer dat Afrikaans op grond van sy verbintenis met die land en die volk die grootste en beste kans op voortbestaan het) asook D.F. Malan se toespraak "Het is ons emst" op 13 Augustus 1908 te Stellenbosch (waarin hy onder meer sê: "Verhef de Afrikaanse taal tot schrijftaal, maak haar de draagster van onze kultuur, van onze geschiedenis, onze nationale idealen, en gij verheft daannede ook het volk dat haar spreekt" - vgl. Pienaar 1943:310) uitsprake wat almal bygedra het om 'n groter bewustheid te bly kweek vir Afrikaans in die belangrike wordingstyd. Danksy die onvermoeide ywer van talle taalyweraars is daarin geslaag om in die grondwet van die Unie van Suid-Afrika 
(Artikel 137) erkenning te kry vir Hollands op gelyke voet naas Engels. ${ }^{4}$ Dit was op sigself al 'n groot prestasie om in die loop van slegs agt jaar na die afloop van die Anglo-Boereoorlog hierdie erkenning te kry, veral in die lig van Milner se verklaarde begeerte om Engels dié taal van Suid-Afrika te maak. Steyn (1980: 188-191) sê dat deur hierdie erkenning die nodige staatkundige raamwerk vir Afrikaans geskep is om te oorleef en uiteindelik die erkende hoë funksies by Hollands (naamlik as skool-, kerk- en staatstaal) binne die volgende 15 jaar oor te neem.

'n Mens kan seker ten regte hier verwyte maak - soos L.T. du Plessis (1992) dat die nasionalistiese siening van taal en volk wat hier bo benadruk is, in die lig van vandag se perspektiewe nie noodwendig bevorderlik vir die taal was nie omdat dit een van die hoofredes is wat daartoe bygedra het om die verband tussen Afrikaans en die blanke sprekers daarvan so eng te maak. Zietsman (1992:188) waarsku egter "... dat ons net met die oog van die hede na dergelike ontwikkelinge sal kyk en die perspektief wat hulle in hulle eie tydsverband verstaanbaar maak, uit die gesig verloor". Dit beteken dat taalnasionalisme nie noodwendig net verkeerd is nie en dat daar begrip daarvoor moet wees - voorbeelde hiervan word ook meer as genoeg aangetref in die briewe waarvan vroeër melding gemaak is. Nasionalisme kan wel verkeerd raak as die klem net op die etniese aspek van nasionalisme val, want dan word die onderlinge groeps- en rasseverskille die oorheersende onderskeidingsfaktor en speel taal- en kultuurooreenkomste geen rol nie. Nasionalisme wat op taal gemik is, kan bydra om 'n taal se voortbestaan te verseker - met hierdie siening kan sekerlik nie te veel gestry word nie. As spreker van Afrikaans hoef ek seker nie te sê ek is skaam omdat ek Afrikaans praat nie - as ek dit gebruik, is ek onbeskaamd trots op my taal en dit waarvoor hy staan: 'n unieke kommunikasiemiddel wat sterk geanker is aan die bodem van Afrika. In die lig hiervan verklaar Hans du Plessis (1992:37):

Ek wil deel wees van ' $n$ nuwe Suid-Afrika, en my bydrae wil ek ernstig en eerlik en dinamies lewer, maar: ek wil dit in Afrikaans lewer ... Ek wil voluit kan leef in die taal van my keuse, nie die taalkeuse van 'n nuwe regering nie.

4 Artikel 137 van die Uniegrondwet van 1910 lui soos volg: "Both the English and Dutch languages shall be official languages of the Union, and shall be treated on a footing of equality, rights and privilige; all records, joumals and proceedings of Parliament shall be kcpt in both languages, and all Bills, Acts, and notices of general 'importance or interest issued by the Government of the Union shall be in both languages"' (vgl. Pienaar, 1993: 321). Op $8 \mathrm{Mei} 1925$ word eenparig in die Volksraad besluit: "Het woord 'Hollandse' in artikel honderd-seven-en dertig van de Zuid-Afrika Wet, 1909, en elders in die Wet waar dat woord voorkomt, word hierby verklaard het Afrikaans in te sluiten" (in die Wet op de Officięle Talen van de Unie, No. 8 van 1925) (vgl. Pienaar, 1943:368) wat inderdaad betcken dat Afrikaans, naas Engels, verklaar word tot amptelike landstaal van Suid-Afrika. 


\section{Perspektief}

F.I.J. van Rensburg (1991:14) sê dat die openlike aanhang van Engels - soos reeds weerspieël word op soveel gebiede: handel, sport, ensovoorts - deur Afrikaanssprekendes toegeskryf kan word aan ' $n$ verlies van historiese perspektief op die geskiedenis van Afrikaans. Die stryd om die erkenning van Afrikaans as volwaardige taal in Suid-Afrika was 'n lang en moeisame pad (en by tye is daar ook lekker kleigetrap), maar die eindresultaat van hierdie proses is iets waarop elke Afrikaanssprekende kan trots wees. Daarom is die "... huidige handdoekingooiery deur Afrikaanssprekendes (...) in meer as een opsig ironies", want "Afrikaans staan vandag veel sterker as in die dae van die GRA" (Beeld, 3/12/1991) - dis voortydig om nou reeds te sê: Afrikaans gaan die hernieude stryd om erkenning verloor. Die boetedoenings- en jammersê-periodes is al verby en nog steeds word dit nie aanvaar nie. Dr. Piet Muller sê dit help nie om te wens "... dat die geskiedenis liewer nie plaasgevind het nie, want wat in die verlede gebeur het, kan nooit weer ongedaan gemaak word nie" (Rapport, 5/12/1993:22). 'n Briefskrywer in Rapport (5/12/1993:18) sê dat die Afrikaanssprekende

... die afgelope paar jaar die slaansak van elke Jan Rap en sy maters geword (het). Al wat Afrikaner, Afrikaanssprekende, Afrikaanse organisasie en Afrikaanse meeloper is, moet gegesel word 'tot den bloedens toe'.

Hans du Plessis (1993:8) vra daarom waarom net Afrikaans in die slag moet bly as tale uitgesonder word. Tans lyk dit asof Engels die uitverkore taal (die language of record) in Suid-Afrika gaan wees as die tekens reg gelees word: die onderhandelinge oor ' $n$ nuwe grondwet was net in Engels, die handel gee voorkeur aan Engels, ensovoorts. ' $n$ Analogie is hiervoor in die taalgeskiedenis te vind Selbourne het nie juis daarmee fout gevind dat vroee Afrikaans ("the Taal") deur Afrikaanssprekendes "with the utmost freedom at their sole discretion" gebruik is nie (hoofsaaklik omdat hy geglo het dat Afrikaans nie die potensiaal gehad het om tot 'n kultuurtaal verhef te word nie), net solank Engels die taal van die parlementêre rekords (language of record) gebly het (vgl. Zietsman, 1992:172) En dan is daar die vraag of Engels met sy rekord van imperiale onderdrukking in die geskiedenis aanspraak kan maak op so ' $n$ skoon verlede en waarom juis hy uitgesonder moet word?

Koerantberigte van die afgelope tyd toon enersyds 'n strydlustigheid oor die voortbestaan van Afrikaans en andersyds 'n gedemoraliseerdheid. Afrikaans het wel erkenning gekry as een van die amptelike tale van die nuwe Suid-Afrika, maar dit kom voor asof daar tans 'n soort politieke gedienstigheid hom meester maak van die taalgebruiksituasie - waarskynlik in afwagting van die verwagte nuwe regering om politieke guns te wen (vgl. dr. Piet Muller, Rapport, 9/1/1994: 14). Dit is asof die weg van die minste weerstand gevolg word en hierdeur word 
Engels onregverdig bo die ander tale in die land bevoordeel. Aan die ander kant is daar ook weer ' $n$ spreekwoordelike 'tier' in die Afrikaanssprekende se 'tenk' losgemaak deurdat soveel Afrikaanssprekendes 'n groter bewuswording begin toon van hul eie taal:

Mense is weer besig om op te staan vir Afrikaans en om Afrikaans te praat en te lees ... Dis asof Afrikaanssprekendes skielik besef dat kollektiewe optrede ongetwyfeld die resep vir die toekoms is. Hulle wil nie meer hulle taal laat skuil onder die beskennende vlerk van 'n regering van die dag nie. Maar hulle wil ook deur geen regering geminag word nie, nie met hul ryk letterkunde, hul pers, hul kultuur wat taalgebonde is en hulle gewone menswees en familieskap wat uitdrukking vind in die taal wat hulle praat nie (I.L. de Villiers, 1993b:20.)

Dr. J.C. Kannemeyer sê in 'n brief aan Beeld (19/01/1994:8) dat "(o)ns ... dinge ( $k a n)$ verander, ook wat die toekoms van Afrikaans betref, mits ons bereid is om saam te staan en vir ons taal te veg". Volgens die skryfster Audrey Blignaut toon die geskiedenis van Afrikaans dat daar ' $n$ sekere onuitroeibaarheid van dié taal is. "En ek is seker daarvan ons sal ons teensit as ons taalregte aangetas word" (Kalender, 25/11/1993:12).

Om dus aanmekaar ou koeie (soos apartheid en taalnasionalisme) uit die sloot te haal en voor die Afrikaanssprekende se kop te gooi, kan net daardie weerstand wek wat groter bewuswording van die taal en sy moontlikhede kan meebring en daarom teenproduktief kan wees vir diegene wat Afrikaans nie sy regmatige plek in die land wil gun nie. F.I.J. van Rensburg (1994:8) se opmerking in Beeld $(28 / 01 / 1994)$ vat die gedagtes wat hier bo uitgedruk is, netjies soos volg saam:

Ek wil nie misverstaan wees nie. Deur op nugtere feit soos dié te wys, is ' $n$ mens nie besig om ' $n$ chauvinistiese saak vir Afrikaans uit te maak nie. Dis 'n eerlike poging om ' $n$ besluitnorm te vind vir 'n situasie wat oor die potensialiteit van heelwat woede en gisting beskik.

\section{Bibliografie}

Combrink, J. 1993. Afrikaanssprekendes moet tot massa-aksie oorgaan vir taal. Die Burger: 13, Des. 11.

De Villiers, I.L 1993a. Wind, storm en Afrikaner Rapport. 20, Okt. 24.

De Villiers, I.L. 1993b. Afrikaans - die broeiende storm. Rapport. 20, Des. 12

Du Plessis, Hans 1992. En nou, Afrikaans? Pretoria : J.L. van Schaik.

Du Plessis, Hans 1993. Waarom moet net Afrikaans in die slag bly? Afrikaans vandag, 1(2) 8, Julie.

Du Plessis, H. \& Du Plessis, L T (reds.) 1987. Afrikaans en taalpolitiek: 15 opstelle. Pretoria : HAUM Opvoedkundige Uitgewery

Du Plessis, L.T. 1986 . Afrikaans in beweging. Bloemfontein : Patmos

Du Plessis, L.T. 1992. Veranderde opvattings rondom Afrikaans sedert die sewentigerjare. In: Webb, V.N (red ) Afrikaans ná apartheid Pretoria : J.L van Schaik. p. 91-115. 
Muller, P. 1993a Gee ons taalvrede. Rapport 18, Okt. 31

Muller, P. 1993b. Hou op soebat, Afrikaner. Rapport. 16, Nov 28

Muller, P 1993c. Waar's die flêtse, oom? Rapport: 22, Des 5.

Muller, P. 1994. Strategie vir taalstryd Rapport: 14, Jan. 19.

Pienaar, E.C. 1943. Die triomf van Afrikaans Kaapstad : Nasionale Pers Bpk

Prinsloo, K.P. \& Van Rensburg M.C.J (reds.) 1984. Afrikaans: stand, taak, toekoms Pretoria : HAUM Opvoedkundige Uitgewery.

Steyn, J.C. 1980. Tuiste in eie taal. Die behoud en bestaan van Afrikaans. Kaapstad Tafelberg

Steyn, J.C. 1987. Trowwe Afrikaners. Aspekte van Afrikanernasionalisme en Suid-Afrikaanse taalpolitiek 1875-1938. Kaapstad: Tafelberg

Swanepoel, P. 1992. Taal, emosies en die toekoms van Afrikaans In: Webb, V. N. (red.). Afrikaans ná apartheid. Pretoria : J.L. van Schaik. p. 119-163

Van de Rheede, I 1983. Kommentaar oor enkele aspekte van "Kleurling-Afrikaans". Standpunte, 168: 30-33.

Van Rensburg, F.I.J. 1991. Afrikaans: belangrike stuk geskiedenis vergeet Beeld: 14, Des. 3

Van Rensburg, F I.J. 1993. Die les wat die Afrikaner nooit weer moet vergeet nie. Beeld. 9, Nov. 12

Van Rensburg, F.I.J 1994. Kriegler en kommissie moet oor taal weer besin. Beeld: 8, Jan. 28.

Webb, V N (red.) 1992. Afrikaans ná apartheid. Pretoria : J.L. van Schaik.

Zietsman, P.H 1992 Die taal is gans die volk. Woelinge en dryfuere in die siryd om die Afrikaner se taal. Pretoria : UNISA-Uitgewersdienste.

\section{Potchefstroomse Universiteit vir CHO}


